\title{
The asthenosphere low-velocity layer
}

\author{
B. Gutenberg \\ ricevuto il 23 settembre 1959
}

Over 100 years ago, Airy and Pratt independently concluded that the weight of a rock column of a given cross section above a depth of the order of $100 \mathrm{~km}$ is about the same everywhere regardless of the elevation of the surface of the earth. Airy assumed that the greater height of mountains is compensated by greater thickness of the relatively light crustal material below them, while Pratt believed that the density of the crustal material under mountains is smaller than that under lowlands. Dutton (1889) introduced the expression isostasy for the "tendency to bulge", where the lighter material exists, and, "where the denser matter existed, ... to depress the surface". Barrell (1914) pointed out that the maintenance of isostasy requires that below the relatively strong, mainly crustal "lithosphere" there is a layer with smaller yield strength, which he called "astenosphere" (1914, p. 659). He assumed that below the asthenosphere the yield strength is greater again, and that processes requiring gradual movements take place mainly in the asthenosphere. His ideas have been extended by Daly (1940) and others.

At least as early as 1907 , v. Wolff had concluded that at depths near $100 \mathrm{~km}$ the temperature should be close to the melting point of ultrabasic material. Gutenberg (1926) investigated if earthquake waves show a corresponding appreciable decrease in velocity. He studied the amplitudes of longitudinal waves of shallow earthquakes as a function of distance up to $3000 \mathrm{~km}$ and found that starting at a distance of about $200 \mathrm{~km}$ from the source the amplitudes of longitudinal waves decrease roughly exponentially with distance and reach a minimum near an epicentral distance of about $1700 \mathrm{~km}$, where they increase suddenly by a factor of roughly 100. From these results he concluded that there is a slight decrease in the velocity of longitudinal waves at a depth of about $75 \mathrm{~km}$, but no indication of molten material. This "asthenosphere low velocity layer", as he called it later to distinguish it from 
lithosphere low velocity layers, has been ever since the subject of investigations with more and more improved methods and results.

Byerly (1926) noticed that the travel time curve of longitudinal waves consists of several portions with different slope, and that at a distance of about $20^{\circ}$ " there appears to be a rather abrupt increase in the apparent surface velocity". Subsequently, this discontinuity in the slope of the travel time curve, which has been found for many regions, as well as a discontinuity in the earth which has been assumed to cause this sudden change in slope have been called the "twenty degree discontinuity". The depth of this hypothetical discontinuity in the mantle has been investigated repeatedly by Jeffreys, by Miss Lehmann and by others (see, e. g., Jeffreys, 1959, pp. 98-102), who found for its depth values of between about 200 and $500 \mathrm{~km}$. On the other hand, investigations of travel times of longitudinal waves by Gutenberg and Richter $(1935$, p. 339) confirmed Gutenberg's earlier conclusion that at the depths which are reached by the rays emerging at distances of less than $14^{\circ}$ "the velocity may be closely constant, or may even decrease with depth". If it decreases by more than the critical rate, given by $d V / d r=V / r$, " the range from $6^{\circ}$ to $14^{\circ}$, with its small amplitudes, corresponds to a so-called shadow zone, while the large amplitudes just beyond $14^{\circ}$ may represent a focal point" (Gutenberg and Richter, 1935, p. 339); compare Figure 1. They found no indication of a discontinuity.

Gutenberg and Richter (1939, p. 531) realized that " additional information bearing on this problem can be derived from a study of seismograms of deep shocks recorded at short distanced". They selected earthquakes originating at depths between 50 and $250 \mathrm{~km}$ which had been recorded at Huancayo, Peru, at distances of between 2 and 23 degrees. They found that the shadow zone at the surface has its greatest extent, when the source is at a depth of about $80 \mathrm{~km}$, and that it rlisappears, if the source is deeper than roughly $200 \mathrm{~km}$. They concluded $(1939$, p. 537) that this confirms and extends "the conclusion that a slight decrease in the velocity of longitudinal waves occurs at a depth of about $80 \mathrm{~km}$. Quantitative data have then been given by Gutenberg (1945, p. 126; see also Gutenberg, 1959 b, p. 85) when he discussed the determination of magnitudes of deep focus earthquakes on the basis of amplitudes of $P$ and $\mathrm{S}$. He concluded $(1945$, p. 129) that "the shadow zone for $\mathrm{P}$ and $\mathrm{S}$ waves at epicentral distances near $10^{\circ}$, indicating a slight minimum in wave velocity at a depth near $100 \mathrm{~km}$, has been confirmed".

In an "attempt to find more accurately this decrease in wave velocity with increasing depth" Gutenberg (1948) investigated seismo- 
grams of earthquakes which had originated at distances of between to and $25^{\circ}$ from Pasadena. In addition to a confirmation of the earlier results about the amplitudes in and near the shadow zone, he concluded that the travel time curves of $P$ and $S$ " consist of two branches, the first almost a straight line ending in a shadow zone, the second beginning with relatively large amplitudes and with a delay relative to the first branch. .... All observations are explained on the assumption that the velocity of $P$ as well as $S$ waves decreases somewhat (between $1 / 2$ and 3 per cent?) at a depth.... near 80 to $100 \mathrm{~km}$ ". He also pointed out " that such a low-velocity layer has now been established for the solid earth, the ocean, and the atmosphere, providing shadow zones for elastic (sound) waves in all three..... Only a relatively small decrease in velocity is required to produce a rather extensive and pronounced shadow zone". This has been discussed in more detail by Gutenberg $(\mathbf{1 9 5}+\mathrm{b})$.

A new method to find the velocities in the asthenosphere lowvelocity layer was introduced by Gutenberg (1953). He pointed out that the wave velocity $V$ at the depth $h=R-r(R=$ radius of the earth, $r=$ distance of the source of the earthquake from the earth's center) of an earthquake can be found from the apparent velocity $V^{*}$ at the point of inflection of the travel time curve from

$$
V=T^{*} r / R
$$

Gutenberg applied this equation to values of $r^{*}$ found from travel time curves of 82 shocks originating at depths of between about 50 and $600 \mathrm{~km}$, mostly in or near Japan. He constructed curves for the velocity as tunction of depth for $\mathrm{P}$ and $\mathrm{S}$, which show a clear decrease with deptl, below the MIohorovicic discontinuity " with a minimum at a depth of roughly $100 \mathrm{~km}$ for longitudinal waves and $150 \mathrm{~km}$ for transverse waves. Poisson's ratio increases from about 0.26 at a depth of $50 \mathrm{~km}$ to 0.29 at $250 \mathrm{~km} . .$. . Small local differences in the rate of the velocity decrease result in noticeable local differences in amplitudes and perhaps even in travel times at epicentral distances between about $5^{\circ}$ and $20^{\circ}$ ".

If a low-velocity layer exists below the crust, the correspondiug travel time curve may be interrupted (Figure 1). In such instances, the arrival times of $\mathrm{P}$ and $\mathrm{S}$ which are reported by the stations at distances inside the shadow zone may belong to diffracted or to channel waves. Especially, in instances where the source is in the low-velocity layer (Figure 1d), waves leaving the source nearly horizontally do not reach the surface, and the point of inflection of the travel time curve cannot 
be observerl. Usually, such instances are not detected on the basis of the reporterl times, since it is not possible to decide whether a small begrinning of $P$ on a record belongs to a small direct wave or to a

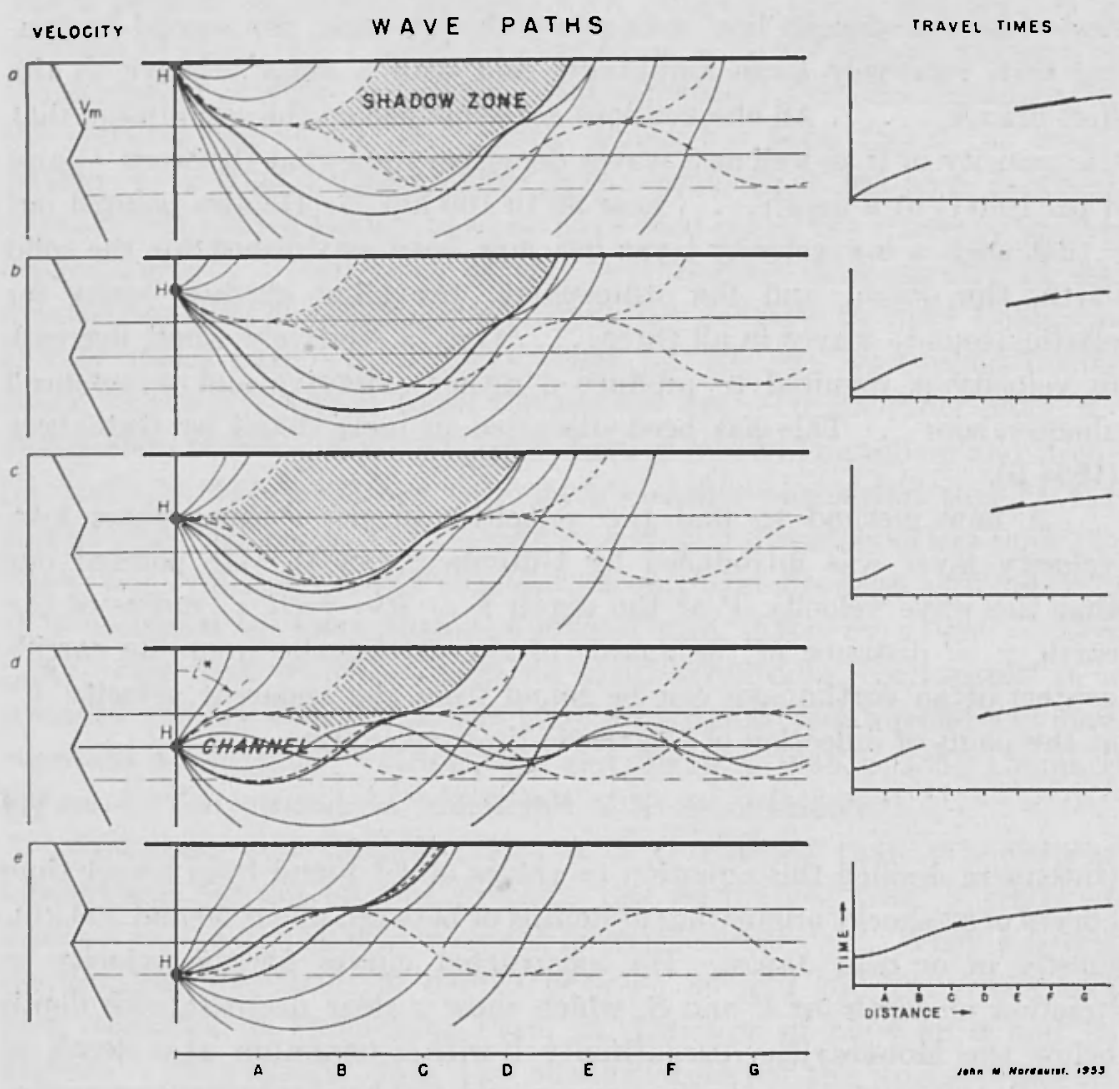

Fig. J. - Sketches of waves paths, travel times and shadow zones for various focal depths if a low-velocity layer exists. The velocity-depth curve at left has been assumed and does not correspond to conditions in the crust and upper mantle (After Gutenberg, 1954b).

diffracted wave or to movement at the surface produced by a channel wave propagated within a few wave lengths below the surface (Figure 1.d). In such instances, a continuous travel time curve is frequently drawn on the basis of all reported times although these may refer to various types of waves. If the apparent velocity at the point of inflection of such a spurious travel time curve is used, equation [1] leads to a result which still is close to the actual velocity at the depth 
of the source. If, however, such a fictitious travel time curve is used to calculate the wave velocity as a function of depth, assumptions may have to be made, including discontinuities (as in the case of the "twenty degree discontinuity") and a spurious velocity-depth curve may be obtained.

A very important discovery was made by Caloi $(1953,1954)$ when he observed and explained correctly two new phases in records of earthquakes originating at depths of between 20 and $200 \mathrm{~km}$. He found that these phases. which he called $\mathrm{Pa}$ and Sa are propagated to great distances with constant velocities of about 8.0 and $4.4 \mathrm{~km} / \mathrm{sec}$ respectively. Caloi explained these phases as waves guided by the low-velocity layer in the asthenosphere. Bath and others consider the possibility that channel waves, especially $\mathrm{I}, \mathrm{g}$, are surface waves of higher modes (I. U. G. G. Chronicle No. 22, 1959, pp. 223, 224). Pa and Sa have been reported independently by Press and Ewing (1955) who suggested tentatively " a mechanism of transmission involving " whispering gallery" propagation in the mantle by multiple grazing reflections from the Mohorovičic discontinuity". The velocities observed by them are 7.98 to $8.24 \mathrm{~km} / \mathrm{sec}$ for Pa-waves, while they observed two Sa-wave types with velocities of 4.58 and $4.4 \mathrm{~km} / \mathrm{sec}$ respectively. They, too, observed these waves in shocks originating at depths of as much as $200 \mathrm{~km}$. Waves originating at foci over about $60 \mathrm{~km}$ deep are no longer grazing the Mohorovičic discontinuity and should loose an appreciable amount of energy at each reflection at the discontinuity, so that the "whispering gallery" explanation can not apply at least in these instances. Gutenberg $(1955 \mathrm{~b})$ found $\mathrm{Pa}$ and $\mathrm{Sa}$ waves in records of the Kern County, California, earthquake of 1952 with velocities of 8.05 and $4.44 \mathrm{~km} / \mathrm{sec}$ respectively at distances to almost 100 . "There is general agreement that $\mathrm{Pa}$ and $\mathrm{Sa}$ waves are found which have travelled through oceanic [subcrustal] layers..... There is no clear evidence that the asthenosphere channel is missing in any of the larger units of the earth's subcrustal layers" (Gutenberg, 1955b, p. 293).

The Kern County, California, earthquake of 1952 has furnished excellent data for the travel times of waves at the epicentral distances involved in the study of the effects of the asthenosphere channel. Gutenberg (1954a) combined these travel times with those from several other well recorded shocks in Southern California (Figure 2). In the interim, it had been well established from travel times of waves generated by earthquakes and by artificial explosions that the velocities of waves refracted immediately below the Mohorovičic discontinuity are between 
8.0 and $8.2 \mathrm{~km} / \mathrm{sec}$ for $\mathrm{P}$ and between 4.6 and $4.8 \mathrm{~km} / \mathrm{sec}$ for $\mathrm{S}$ (see, e. g., Gutenberg, 1955a, p. 23; 1959b, pp. 32-35). Finding of lower velocities than 8.0 and $4.6 \mathrm{~km} / \mathrm{sec}$ respectively in the upper portion of the mantle by Jeffreys and others, e. $g$. increase in the velocity of $P$ from 7.75 $\mathrm{km} / \mathrm{sec}$ below the crust to 7.95 at $100 \mathrm{~km}$ and in that of $\mathrm{S}$ from 4.35

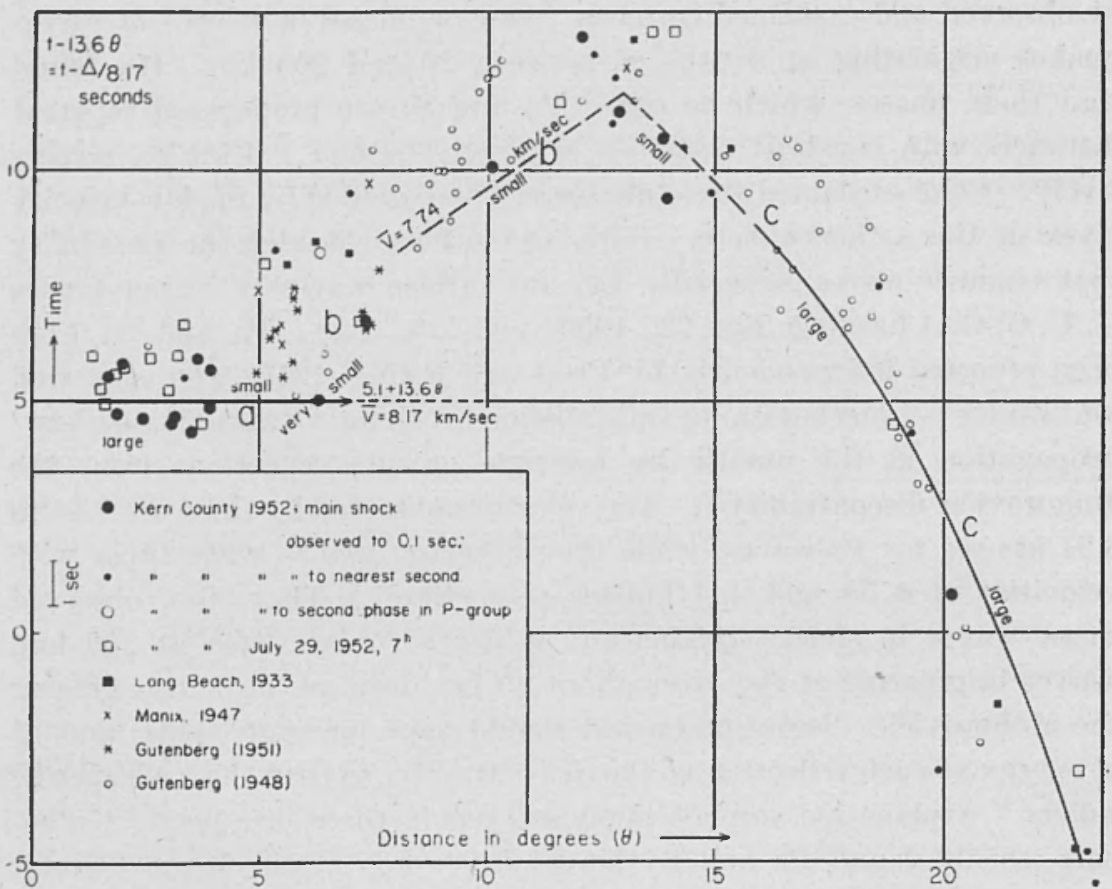

Fig. 2. - Observed travel times of $\mathrm{P}$ minus 13.6 times distance in degrees (subtracterl to permit use of larger time scale) for earthquakes in Southern California (based on Gutenberg, 1954a: see also Gutenberg, J959b, pp. 78 and 79 ).

$\mathrm{km} / \mathrm{sec}$ below the crust to 4.45 at a depth of $100 \mathrm{~km}$ (reproduced, e. $\mathrm{g}$. by Jeffreys, 1959, p. 122 and also by Bullen, 1953, p. 211) contradict the many reliable values obtained from refracted (or diffracted) waves directly below the crust unless a low-velocity layer is assumed.

Longitudinal waves having a velocity of between 8.1 and 8.2 $\mathrm{km} / \mathrm{sec}$ are found in California (Figure 2) at epicentral distances between about $1^{\circ}$ and $7^{\circ}$ with rapidly decreasing amplitudes. Between about $7^{\circ}$ and $13^{\circ}$ the first waves are small and scatter about a straight line cor- 
responding to a velocity of only about 7.7 to $7.8 \mathrm{~km} / \mathrm{sec}$. Starting at about $14^{\circ}$ lougitudinal waves with amplitudes increasing rapidly near about $15^{\circ}$ and indicating a rapid increase in velocity below a depth of about $200 \mathrm{~km}$ are found. Again, these results have been interpreted by Gutenberg (1954a, p. 346) as an effect of the asthenosphere channel. He concluded that the channel "is probably due to a greater effect of the increase in temperature with depth than that of the increase in pressure at the depth where the melting point of the material is appoached, while above and below this channel the effect of the increase in pressure with depth prevails". Gutenberg (1954b) has also sketched the rays originating from earthquakes at various depths in and near the channel, the resulting forms of the travel time curves and of the shadow zones (reproduced in Figure 1). Theoretical computations related to this problem have been carried out by Bath (195i).

Attempts to evaluate theoretically the temperature gradient necessary to produce a low-veloeity layer in the asthenosphere have been made by Valle (1956). He concluded that a gradient in excess of $14 \% / \mathrm{km}$ is necessary for a low-velocity layer for $P$ waves, and in excess of $11 \% / \mathrm{km}$ for $\mathrm{S}$ waves. The actual gradient just below the crust has been estimated by some geophysicists to be greater, by others to be smaller than the critical values calculated by Valle. It may be more accurate now to calculate the temperature gradient from the decrease in wave velocities than vice versa. The relationship of these two quantities has also been studied by Birch (1958) but he has applied his equations only to crustal layers. While on his assumptions the theory does not indicate a decrease in velocity with depth for granite in the crust, a slight decrease is indicated by his curve for gabbro below a depth of about $20 \mathrm{~km}$ (Birch, 1958, p. 167). However, all such numerical results depend on the rather uncertain values of the temperature as a function of depth (Figure 3).

Esperimental data on the effect of temperature and pressure on rocks have been published by Hughes and Maurette (1957) and by Birch (1958). On the assumption of plausible values for pressure and temperature in the earth's crust Hughes and Maurette find that in granites and in several basic igneous rocks the wave velocities can be expected to increase with depth in roughly the upper ten $\mathrm{km}$ of the crust and to decrease with depth below about $10 \mathrm{~km}$. On the same assumptions they find that in dunite which is considered sometimes to be representative of the material in the asthenosphere, the velocities of both wave types should reach a maximum already under the conditions at a depth of about $5 \mathrm{~km}$. 
The investigation of records obtained from atomic explosions again confirmed the existence of the shadow zone at distances between roughly 1000 and $2000 \mathrm{~km}$ from the source (Anonymous, 1958). On the basis

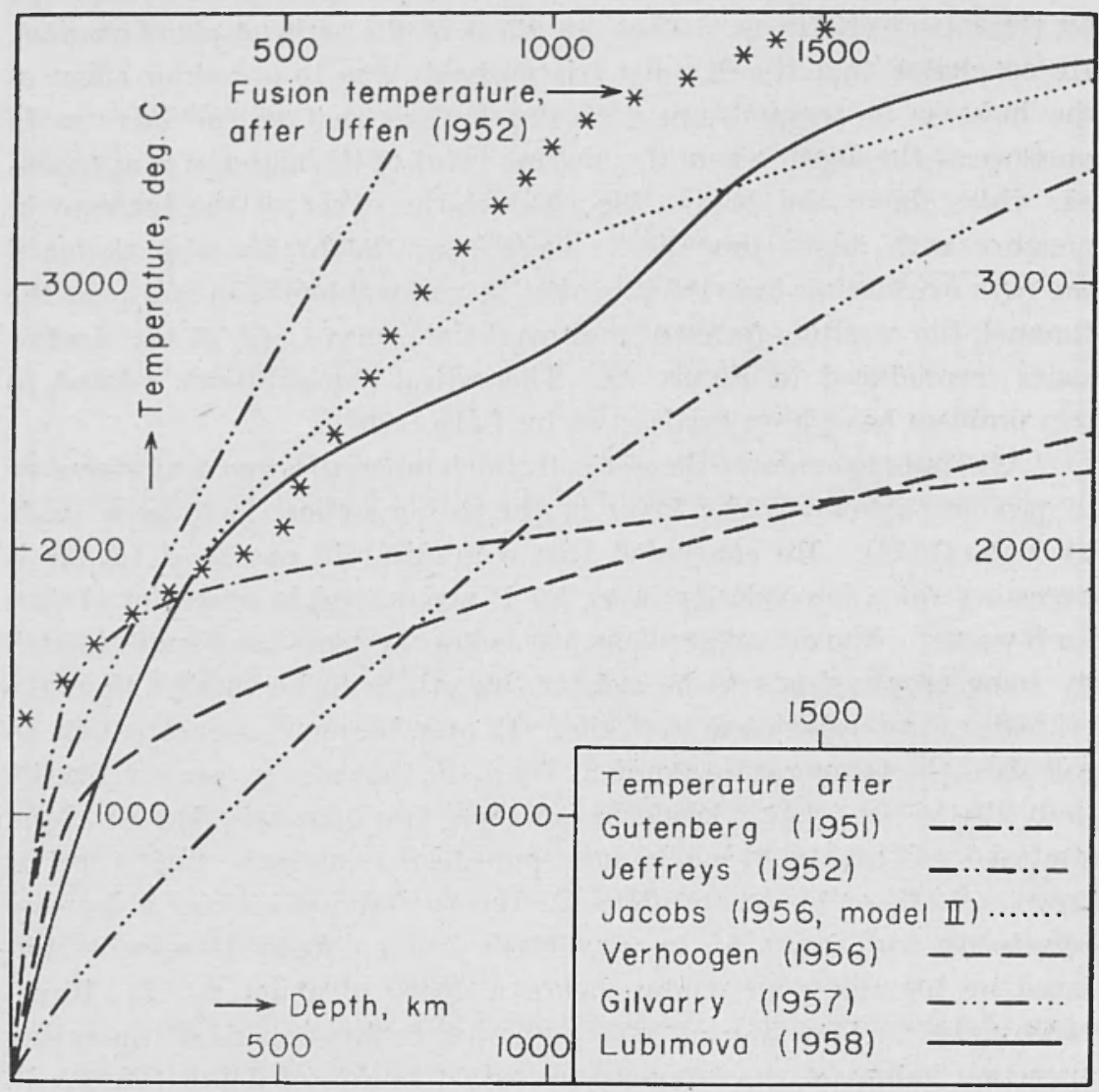

Fig. 3. - Temperature in the upper portion of the eartlis mantle according to various authors; fusion temperature after Uffen (1952) based on the velocity of seismic waves.

of the increasing evidence for the asthenosphere channel, Gutenberg (1958) has suggested to identify Bullen's region B with the asthenosphere and to put its lower boundary tentatively and somewhat arbitrarily at a depth of $200 \mathrm{~km}$. Problems connected with the " twenty degree discontinuity" have been discussed in more detail by Gutenberg (1959b, pp. 75-89). 
As has been pointed out it had been found over 50 years ago that the temperature in the upper mantle must be close to the melting point. There are still no reliable data available, how close the temperature comes to the melting point; Figure 3 gives some estimates of the temperature as a function of depth as well as a curve for the melting point which has been calculated by Uffen (1952) by use of seismic data on the basis of the Einstein-Debye theory of solids and Lindemann's theory of fusion. Figure 3 shows that at depths of between 100 and $300 \mathrm{~km}$ the temperature in the earth may indeed be close to the melting point of the material. Additional important evidence has been given by Gorshkov (1958) who reported that transverse waves from Japanese earthquakes are not recorded in Kamtchatka, if the waves have to travel under the belt of volcanoes, while they are well recorded at about the same distances at stations to which the wave paths are to the west or east of this belt. Gorshkov concluded that there seem to be magmatic foci at a depth of roughly $60 \mathrm{~km}$. Their "occurrence.... in the upper" part of the mantle is probably far from being casual and is connected with a velocity decrease of seismic waves" (Gorshkov, 1958, p. 28). "The most probable reason for this phenomenon is a transition from a crystalline state into an amorphous condition" (Gorshkov, 1958. p. 109). These results give additional weight to the over fifty year old concept of the asthenosphere as a relatively weak layer, in which gradual movements, subcrustal currents, movements to make isostasy possible, and movements of extended portions of continental blocks relative to the main portion of the mantle may take place more easily than in the lithosphere.

More recently, observations of surface waves have added new evidence for the asthenosphere low-velocity channel. Intependent investigations of Takeuchi, Press and Kobayashi (1959) and of Dorman, Ewing and Oliver (1959) indicate that the observed dispersion curve for Rayleigh waves agrees better with calculated curves, if a low-velocity layer of the type discussed here is assumed than on the assumption that the relocities increase with depth and have a discontinuity. Moreover, according to Landisinan, Sato and Ewing (1959) the dispersion curve for Love waves indicates a low-velocity layer for shear waves at depths of roughly 100 to $200 \mathrm{~km}$ under continents.

Press (1959) has found that "G-wave relocities for continental and oceanic paths do not differ by more than about 2 per cent. Since their relocity is controlled by the asthenosphere low-velocity zone, this must be present under contients and oceans". Landisman, Sato and Ewing 
(1959) find that "under oceans the region of low shear velocities rises to depths of about $50 \mathrm{~km}$; the low-velocity zone is thicker, and the velocities are lower than under continents". Unfortunately, velocities of longitudinal waves found from refraction shooting under oceans do not help much in investigations of the low-velocity layer under oceans, since the relorities depend on the locally relatively much differing temperatures in the ocean bottoms at a given depth; moreover, there is some doubt how far the material under the Mohorovičic discontinuity under ocean bottoms differs from that under continental areas and also betiween various oceanic areas (compare Gutenberg, 1959a). Moreover. immediately under the relatively shallow Mohorovicic discontinuity in oceanic areas the wave relocities are possibly lower than at somewhat greater depths.

Vesanen, Nurmia and Porkka (1959) have used time differences $\mathrm{pP}-\mathrm{P}$ to find the depth of the low-velocity channel. They obtain values of $45 \mathrm{~km}$ for Alaska, $80 \mathrm{~km}$ for North Japan, $95 \mathrm{~km}$ for the Tonga region and $120 \mathrm{~km}$ for South America.

The values for the velocities at depths between the Mohorovicic. discontinuity and about $70 \mathrm{~km}$ have been more uncertain than those for greater depths. Gutenberg (1959a) has studied the wave relocities which have been calculated from refracted (or diffracted) waves at the shortest distances where they can be observed on records of earthquakes or of artificial explosions. He has found that these reported velocities decrease with increasing depth of the Mohorovicic discontinuity. Application of the methor of least squares to velocities reported during the past ten years for continental areas give

$$
\begin{aligned}
& V=(8.08 \pm 0.0131)-(0.011 \pm 0.0016)(\mathrm{h}-40) \mathrm{km} / \mathrm{sec} \\
& v=(t .60 \pm 0.044)-(0.00 \pm \pm 0.0056)(\mathrm{h}-40) \mathrm{km} / \mathrm{sec}
\end{aligned}
$$

The rate of decrease in the longitudinal velocity $V$ is statistically significant, that in the transverse velocity $v$ is significant only if it is considered in connection with that for the longitudinal velocity.

To obtain more data on the velocities in the upper portion of the mantle, it seemed advisable to apply equation [1] to travel time curves of $\mathrm{P}$ and $\mathrm{S}$ for additional earthquakes. The accuracy of this method has been tested by applying equation [1] to the travel time curves of Jeffreys and Bullen (1940), who have calculated travel times of $\mathrm{P}$ and $\mathrm{S}$ for various focal depths $h$. Jeffreys and Bullen express the depth $h$ hr the ratio of the radius $r=(R-h)$, where $R$ is the earth's radius, to the 
radius of the average top of the earth's mantle. Since Jeffreys has assumed that in the average the crust is $33 \mathrm{~km}$ thick, the depth 0.00 of Jeffreys-Bullen corresponds to an actual depth of $33 \mathrm{~km}$ or to a radius of $6371-33=6338 \mathrm{~km}$; generally, their depths $h$ correspond to $6338 \mathrm{~h}+$ $33 \mathrm{~km}$ below the earth's surface; for example, $h=0.01$ corresponds to a depth of $96 \mathrm{~km}$. Jeffreys and Bullen have included in these tables for each focal depth the time differences corresponding to consecutive distances; up to $10^{\circ}$ epicentral distance, these differences give the time difference in $\sec / 5^{\circ}$, beyond $10^{\circ}$ in sec/10 $/ 1$. In Table 1 , for each focal

Table I

\begin{tabular}{|c|c|c|c|c|c|c|c|c|c|c|}
\hline $\begin{array}{l}h--33 \\
k-33\end{array}$ & h & $\frac{R}{r}$ & $\begin{array}{l}\frac{1}{\Gamma^{*}} \\
\frac{\text { sec }}{100}\end{array}$ & $\begin{array}{l}l^{*} \\
\frac{\mathrm{km}}{\mathrm{sec}}\end{array}$ & $\begin{array}{c}\mathrm{V} \\
\mathrm{km} \\
\mathrm{sec}\end{array}$ & $\begin{array}{l}\frac{1}{v^{*}} \\
\frac{\sec }{10^{\circ}}\end{array}$ & $\begin{array}{l}v^{*} \\
\text { km } \\
\text { sec }\end{array}$ & $\begin{array}{c}v \\
\frac{\lim }{\mathrm{sec}}\end{array}$ & \multicolumn{2}{|c|}{$\begin{array}{l}\text { assumed } \\
\text { Jeftreys } \\
(1952)\end{array}$} \\
\hline 0.00 & 33 & 0.9948 & $14 t$ & 7.72 & 7.68 & 254 & 4.37 & 4.35 & 7.75 & 4.35 \\
\hline 0.01 & 96 & 0.9848 & 139 & 7.99 & 7.87 & 247 & 4.50 & 4.43 & 7.94 & 4.44 \\
\hline 0.02 & 160 & 0.9749 & 134 & 8.29 & 8.08 & 240 & 4.63 & 4.51 & 8.13 & 4.54 \\
\hline 0.03 & 223 & 0.9648 & 130 & 8.55 & 8.25 & 231 & 4.81 & 4.64 & 8.33 & 4.64 \\
\hline 0.04 & 287 & 0.9549 & 124 & 8.96 & 8.56 & 224 & +.96 & 4.74 & 8.54 & 4.74 \\
\hline 0.05 & 350 & 0.9451 & 120 & 9.26 & 8.75 & 217 & 5. 12 & 4.84 & 8.75 & 4.85 \\
\hline 0.06 & +13 & 0.9352 & 116 & 9.58 & 8.96 & 209 & 5.32 & 4.98 & 8.97 & 4.96 \\
\hline 0.07 & +77 & $0.925 \mathrm{I}$ & 107 & 10.38 & 9.60 & 197 & 5.64 & 5.22 & 9.50 & 5.23 \\
\hline 0.08 & 540 & 0.9152 & 102 & 10.89 & 9.97 & 187 & 5.94 & 5.44 & 9.91 & 5.46 \\
\hline 0.09 & 603 & 0.9053 & 99 & 11.22 & 10.16 & 178 & (6. 24 & 5.65 & 10.26 & 5.67 \\
\hline 0.10 & 667 & 0.8953 & 95 & 11.70 & 10.48 & 171 & 6.50 & 5.82 & 10.55 & 5.85 \\
\hline $\begin{array}{l}\mathrm{km} / \mathrm{s} \\
\text { are } \\
\text { by J } \\
\text { In t } \\
\text { whic } \\
\text { gical } \\
\text { cent }\end{array}$ & $\begin{array}{l}\text { Velc } \\
\text { sec a } \\
\text { the r } \\
\text { leffire. } \\
\text { he fir } \\
\text { h are } \\
\text { l sum } \\
\text { ral d }\end{array}$ & $\begin{array}{l}\text { city } V \\
t \text { the de } \\
\text { eciprocal } \\
\text { y and B } \\
\text { st colum } \\
\text { used by } \\
\text { mary. } \\
\text { istance. }\end{array}$ & n, the & $\begin{array}{l}\text { gitudins } \\
\text { found } \\
\text { he respe } \\
(1940) \mathrm{fc} \\
\text { e corres } \\
\text { reys-Bu } \\
6371 \mathrm{~km}\end{array}$ & $\begin{array}{l}\text { al wave } \\
\text { by app } \\
\text { ective } 1 \\
\text { or focal } \\
\text { ponding } \\
\text { llen and } \\
\text {, radius }\end{array}$ & $\begin{array}{l}\text { s and } \\
\text { lying } \\
\text { inaxim } \\
\text { depth } \\
\text { value } \\
\text { in th }\end{array}$ & $\begin{array}{l}v \text { of } \\
\text { equa } \\
u m \text { v } \\
\text { s } h \text { in } \\
\text { es for } \\
\text { le In }\end{array}$ & $\begin{array}{l}\text { ansve } \\
\text { n [1]. } \\
\text { nes (d } \\
\text { n (sec } \\
\text { le de } \\
\text { nation }\end{array}$ & $\begin{array}{l}\text { rse wav } \\
\bar{\nabla}^{*} \text { an } \\
t / d \Delta)^{*} \\
\text { ond colu } \\
\text { th are } \\
\text { hal seist } \\
-h, \Delta=\end{array}$ & $\begin{array}{l}\text { es in } \\
\text { d } v^{*} \\
\text { iven } \\
\text { min) } \\
\text { iven } \\
\text { holo- } \\
\text { epi- }\end{array}$ \\
\hline
\end{tabular}




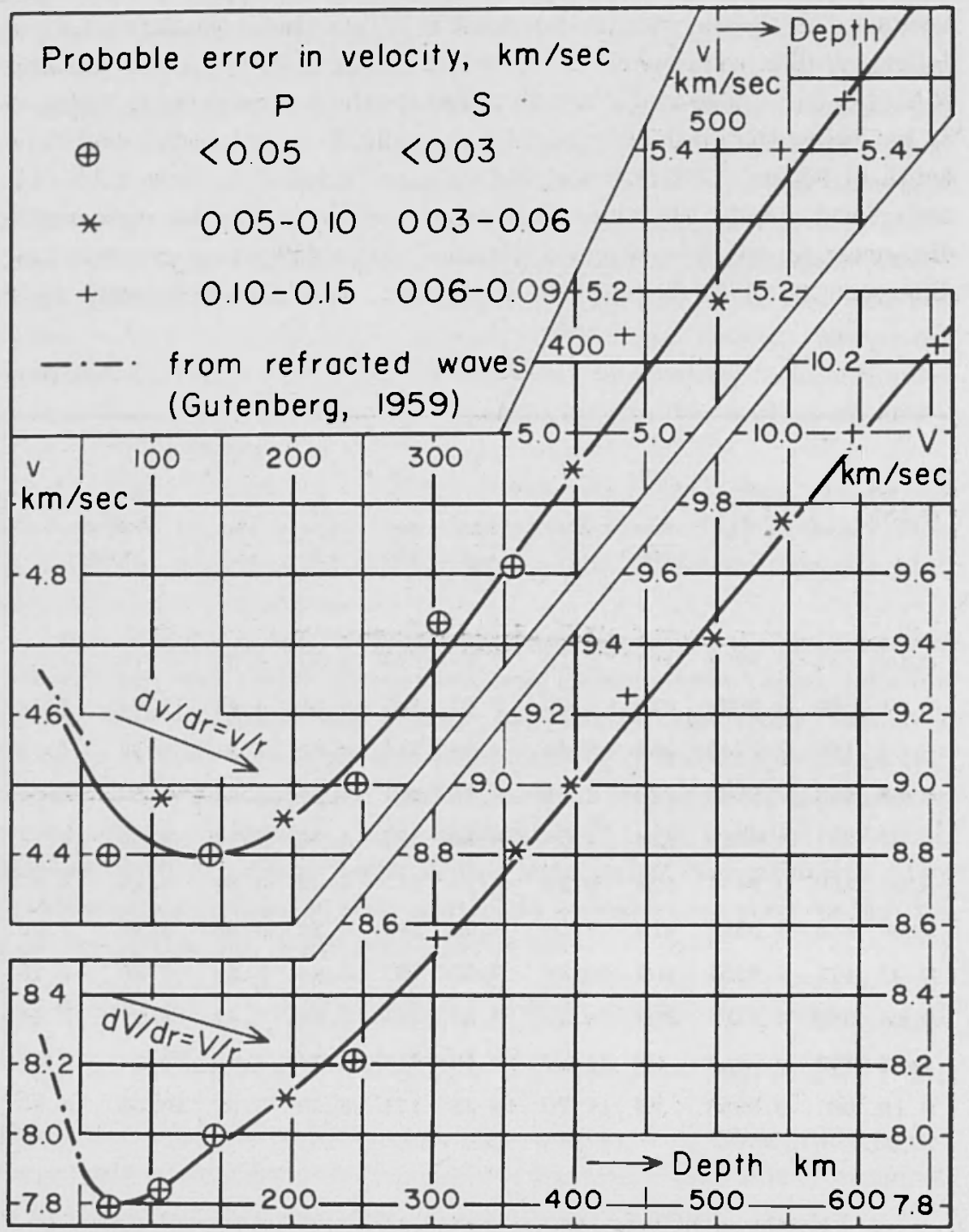

Fig. 4. - Velocities $r$ of longitudinal and $v$ of transverse waves under continents. The beginning of the curves correspond to observations of waves refracted just below the Mohorovicic discontinuity which have been recorded after shallow earthquakes or artificial explosions (Gutenberg, 1959a); data for the individual points aro from Table 3. 
depth their minimum difference, corresponding to the apparent relocity at the point of inflection of the travel time curve for each of their focal depths, is listed (always in sec/10 $)$. This is followed by the corresponding apparent velocity and then multiplied by $r / R$, which is also given in the table. According to equation [1], the result is the actual velocity at the depth $h$. In the last two columns of Table 1 the velocities originally assumed for the ralculations by Jeffreys and Bullen are listed from Jeffreys $(1952$, p. 115, or 1959 , p. 122). The good agreement between these values and the corresponding values found from equation [1] shows that the use of equation [1] does not introduce appreciable errors, and that the travel time curves for various depths calculated by Jeffreys and Bullen (1940) correspond closely to the assumed velocities as function of depth.

It has been pointed out already that for the upper portion of the mantle these velocities are noticeably smaller than the well determined velocities immediately below the Mohorovicic discontinuity (see, e. g. Gutenberg, 1959a; 1959b, pp. 32-35). It follows that closely below the discontinuity there must be either a gradual or a sudden decrease in velocity to the values of Jeffreys-Bullen, if these are correct. On the other hand, the data obtained from refracted waves for the neighborhood of the discontinuity and those for greater depths, based on equation [1] fit one smooth curve (Figure 4).

The velocities found by Gutenberg (1953) had been based on travel times of earthquake waves for the period 1928 to 1940 . No later issues of the International Seismological Summav (ISS) were available in 1953. Inreover, during the war, data of many stations were less reliable than before 1941 or missing. More plentiful and aecurate data start again with 1947 ; at the time of writing the ISS is available as far as the first quarter of 1951. Consequently, the ISS for the period Januay, 1947 to March, 1951 has been searched for earthquakes for which (a) the focal depth could be reliably determined, and (b) a number of arrival times had been reported near the point of inflections of the travel time curves of $P$ or $S$ which were sufficient to determine the values of $F^{*}$ or $v^{*}$. In Table 2 these shocks are listed with the resulting calculated velocities for the respective depths $h$. The procedure was the same as in the earlier paper.

Next, average velocities for certain depth ranges have been calculated. The results for a combination of the old data (1953) with those of the present Table 2 are given in Table 3 . In section. (a) of Table 3 , weights have been used as follows: for 1928 to 1940 a weight 2 for results 
'Tablo 2

\begin{tabular}{|c|c|c|c|c|c|c|c|c|c|}
\hline \multicolumn{3}{|c|}{ Date } & Region & Jalt. & Iong. & $h$ & \multicolumn{3}{|c|}{$\begin{array}{cc}\text { Velocity and } \\
p^{\prime}\end{array}$} \\
\hline \multirow{8}{*}{1947} & Jan. & 30 & IIindIu Kuslı & $36 \mathrm{~N}$ & $7 / \mathrm{E}$ & 200 & $7.6 \mathrm{C}$ & I) & \\
\hline & Feb. & 4 & N. Japan & $42 \mathrm{~N}$ & $143 \mathrm{E}$ & 60 & $7.7 \mathrm{~B}$ & 4.3 & $C^{\prime}$ \\
\hline & Feb. & 18 & Marianne Is. & $33 \mathrm{~N}$ & $137 \mathrm{E}$ & 440 & $9.1 \mathrm{~B}$ & 5.4 & $B$ \\
\hline & Sept. & $\mathbf{l}$ & ()fi Italy & $40 \mathrm{~N}$ & $15 \mathrm{E}$ & $250+$ & $8.2 \mathrm{~B}$ & 4.5 & $\mathrm{C}$ \\
\hline & oct. & 3 & Marianne Is. & $31 \mathrm{~N}$ & $139 \mathrm{E}$ & 380 & $8.6 \%$ & 4.8 & $B$ \\
\hline & oct. & 29 & N. Japan & $4+\mathrm{N}$ & $145 \mathrm{E}$ & 110 & $7.9 \mathrm{~B}$ & 4.6 & C \\
\hline & Nov. & 14 & N. Japan & $44 \mathrm{~N}$ & $143 \mathrm{E}$ & 180 & $8.0 \mathrm{~B}$ & 4.5 & $\mathrm{~B}$ \\
\hline & Dec. & 7 & IIindı Kush & $37 \mathrm{~N}$ & $70 \mathrm{E}$ & 230 & $8.0 \mathrm{~B}$ & 4.5 & $B$ \\
\hline \multirow[t]{11}{*}{1948} & March & 13 & Rumania & $46 \mathrm{~N}$ & $27 \mathrm{E}$ & 190 & $8.1 \quad B$ & I) & \\
\hline & Marels & 15 & Marianne Is. & $32 \mathrm{~N}$ & $138 \mathrm{E}$ & 370 & $8.9 \mathrm{~B}$ & I) & \\
\hline & $A_{\text {pril }}$ & 11 & Marianne Is. & $33 \mathrm{~N}$ & $136 \mathrm{E}$ & 430 & $9.2 B$ & 1) & \\
\hline & April & 29 & Rumania & $46 \mathrm{~N}$ & $27 \mathrm{E}$ & 160 & $8.2 \mathrm{C}$ & I) & \\
\hline & May & 29 & Rumania & $46 N$ & $27 \mathrm{E}$ & 140 & 8.20 & I) & \\
\hline & July & 18 & Ilindu Kuslı & $37 \mathrm{~N}$ & $71 \mathrm{E}$ & 220 & $8.4 \mathrm{~B}$ & I) & \\
\hline & Sept. & 5 & Marianne Is. & $30 \mathrm{~N}$ & I39 E & 400 & $8.8 B$ & 5.05 & $B$ \\
\hline & Sept. & 7 & Hindu Kush & $36 \mathrm{~N}$ & $7 / \mathrm{E}$ & 210 & $8.0 \mathrm{~B}$ & 4.35 & $\mathrm{C}$ \\
\hline & sept. & 11 & East Mediterr. & $37 \mathrm{~N}$ & $23 \mathrm{E}$ & 80 & $7.9 \mathrm{~B}$ & 4.4 & $\mathrm{C}$ \\
\hline & Nov. & 10 & Marianne Is. & $30 \mathrm{~N}$ & $1+1 \mathrm{E}$ & 110 & $7.8 B$ & I) & \\
\hline & Nov. & 15 & Marianne Is. & $29 \mathrm{~N}$ & $139 \mathrm{E}$ & 440 & $9.0 \mathrm{~B}$ & 4.95 & $\mathrm{C}$ \\
\hline 1949 & Jan. & 13 & Kermadec & $26 \mathrm{~s}$ & $178 \mathrm{E}$ & 670 & $10.1 \mathrm{C}$ & 5.8 & $\mathrm{C}$ \\
\hline \multirow[t]{12}{*}{ - } & Wareh & 11 & Hindu Kush & $37 \mathrm{~N}$ & $71 \mathrm{E}$ & 240 & $8.25 B$ & 4.5 & C: \\
\hline & Mareh & 19 & S. Japan & $31 \mathrm{~N}$ & $130 \mathrm{E}$ & 160 & $7.9 \mathrm{~B}$ & I) & \\
\hline & May & 10 & Ilindu Kush & $36 \mathrm{~N}$ & $71 \mathrm{E}$ & 140 & $7.9 \mathrm{~B}$ & I) & 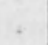 \\
\hline & Juno & 12 & S. America & $27 \mathrm{~s}$ & $63 \mathrm{~W}$ & 600 & $10.0 \mathrm{C}$ & 5.5 & $\mathrm{C}$ \\
\hline & Aug. & 17 & N. Japan & $43 \mathrm{~N}$ & $146 \mathrm{~K}$ & 80 & $7.9 B$ & 4.35 & $\mathrm{C}$ \\
\hline & Sept. & 23 & Siberia & $44 \mathrm{~N}$ & $134 \mathrm{E}$ & 430 & $8.8 \mathrm{~B}$ & 5.05 & 13 \\
\hline & oet. & 25 & Japan & $36 \mathrm{~N}$ & $141 \mathrm{E}$ & 100 & $7.6 \mathrm{C}$ & I) & \\
\hline & Nov. & 3 & Kurile Is. & $48 N$ & $154 \mathrm{E}$ & 160 & $7.7 \mathrm{C}$ & I) & \\
\hline & Nov. & 17 & Marianne Is. & $32 \mathrm{~N}$ & $137 \mathrm{E}$ & 430 & 9.10 & I) & \\
\hline & Dee. & 18 & New Zealand & $35 \mathrm{~S}$ & $180 \mathrm{E}$ & 200 & $8.2 B$ & 1) & \\
\hline & Der. & 21 & s. Amerima & $19 \mathrm{~s}$ & $64 \mathrm{~W}$ & 610 & $10.2 B$ & 1) & \\
\hline & Der. & 26 & Rumania & $46 \mathrm{~N}$ & $27 \mathrm{E}$ & 140 & $8.1 \mathrm{C}$ & 1) & \\
\hline \multirow[t]{3}{*}{1950} & Jan. & 12 & N. Japan & $42 \mathrm{~N}$ & $142 \mathrm{E}$ & 110 & $7.9 \mathrm{~B}$ & 4.55 & 13 \\
\hline & Jan. & 13 & Japan & $38 \mathrm{~N}$ & $142 \mathrm{E}$ & 60 & $7.5 \mathrm{~B}$ & $4.3 \pm$ & $=C^{\circ}$ \\
\hline & Jan. & 16 & Rumania & $46 \mathrm{~N}$ & $27 \mathrm{E}$ & 130 & $8.0 \mathrm{C}$ & 4.5 & C \\
\hline
\end{tabular}


T'able 2 (continued)

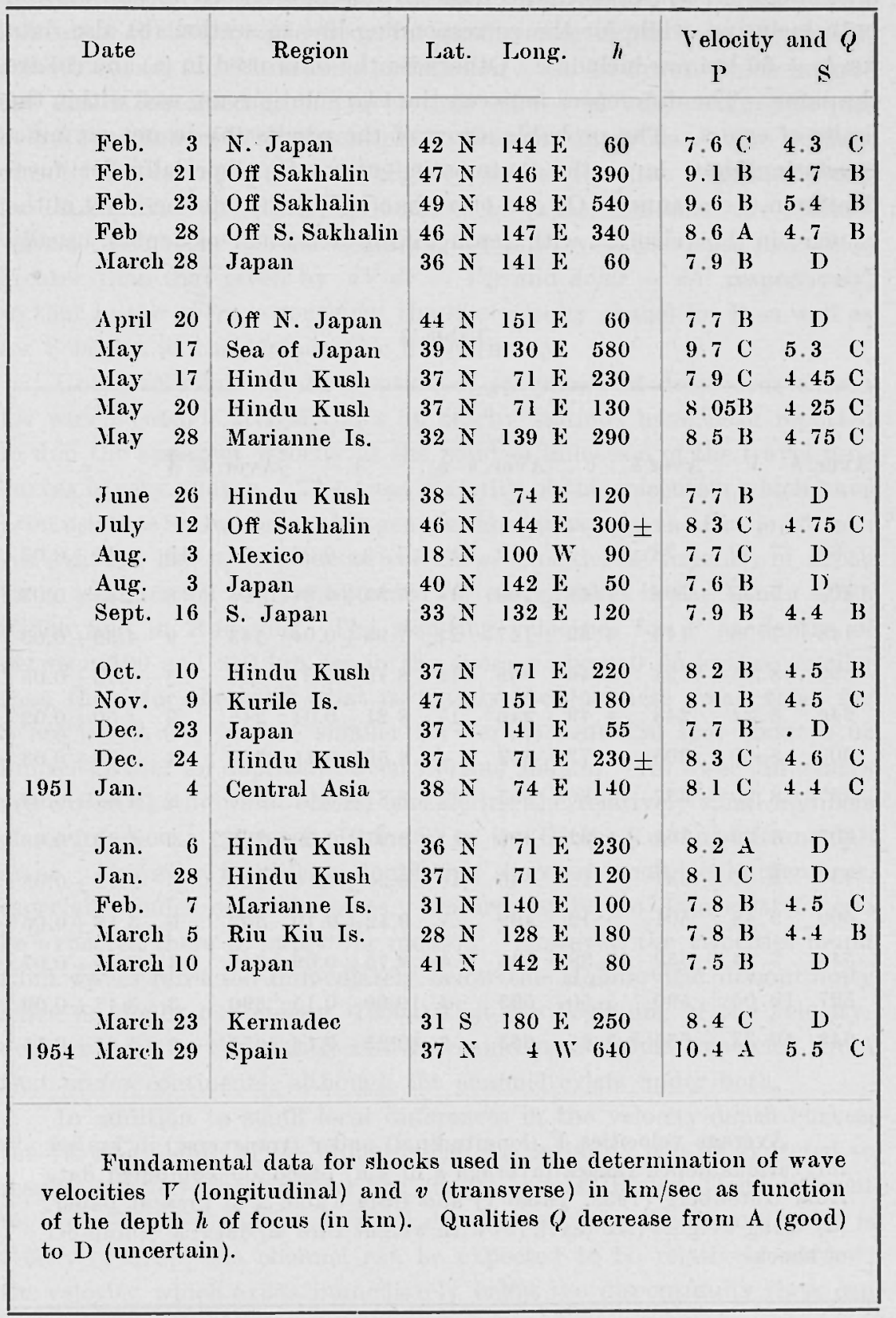


of quality $A, 1$ for $B$; for the uew data, 3 for $A, 2$ for $B$ and 1 for $C$. In section (b) of Table 3 , all results have been given equal weight. The first line of section (a) contains data for depths between 70 and $90 \mathrm{~km}$, both inclusive, while for the corresponding line in section (b) also data for $h=60 \mathrm{~km}$ are included. Otherwise the data used in (a) and (b) are the same. The differences between the two solutions are well within the limits of error's. The probable errors of the results (b) do not permit a conclusion, how large the systematic errors are, especially for focal depths in the channel. On the other hand, they include the effect of the changes in the velocities with depth within each range of depths, usually

Table 3

\begin{tabular}{|c|c|c|c|c|c|c|c|c|c|}
\hline \multicolumn{4}{|c|}{ (a) } & \multicolumn{6}{|c|}{ (b) } \\
\hline Aver. & h $\quad V$ & Aver $h$ & $v$ & Aver. $h$ & $n$ & $r$ & Aver. $h$ & $n$ & $v$ \\
\hline 82 & 7.80 & 78 & 4.44 & 72 & 16 & $7.79 \pm 0.04$ & 70 & 10 & $4.40 \pm 0.03$ \\
\hline 108 & 7.85 & 108 & 4.47 & 109 & 14 & $7.85 \pm 0.04$ & 108 & 8 & $4.48 \pm 0.03$ \\
\hline 148 & 7.98 & 145 & 4.39 & 147 & $2]$ & $7.98 \pm 0.04$ & +3 & 9 & $4.39 \pm 0.03$ \\
\hline 199 & 8. 11 & 194 & 4.46 & 199 & 12 & $8.10 \pm 0.07$ & 194 & 5 & $4.45 \pm 0.05$ \\
\hline 246 & 8.21 & 248 & 4.49 & 246 & 17 & $8.21 \div 0.04$ & 245 & 9 & $4.50 \pm 0.02$ \\
\hline 303 & 8.60 & 305 & 4.72 & 303 & 4 & $8.56 \pm 0.11$ & 303 & + & $4.73 \pm 0.03$ \\
\hline 357 & 8.80 & 357 & +.80 & 357 & 11 & $8.81 \pm 0.07$ & 356 & 8 & $4.81 \pm 0.03$ \\
\hline 395 & 8.90 & 394 & 4.92 & 396 & 11 & $8.97 \pm 0.09$ & 397 & 9 & $4.85 \pm 0.06$ \\
\hline 436 & 9.27 & 437 & 5.18 & 436 & 10 & $9.26 \pm 0.10$ & +37 & 8 & $5.14 \pm 0.08$ \\
\hline 500 & 9.48 & 501 & 5.19 & 499 & 7 & $9.42 \pm 0.10$ & 502 & 6 & $5.18 \pm 0.05$ \\
\hline 544 & 9.74 & 552 & ร. 38 & 545 & 4 & $9.75 \pm 0.09$ & 545 & 4 & $5.40 \pm 0.07$ \\
\hline 597 & 10.05 & 590 & 5.50 & 595 & 4 & $10.00 \pm 0.15$ & 590 & 3 & $5.47 \pm 0.09$ \\
\hline 648 & 10.33 & 655 & 5.65 & 655 & 2 & $10.25 \pm 0.16$ & 655 & 2 & $\tilde{5} .6 \tilde{5} \pm 0.15$ \\
\hline $\begin{array}{l}\text { for } \\
\text { from } \\
\text { (a) } \\
\text { of sl }\end{array}$ & $\begin{array}{l}\text { Avera } \\
\text { various } \\
\text { n Guter } \\
\text { using w } \\
\text { hocks. }\end{array}$ & $\begin{array}{l}\text { velo } \\
\text { pth } \\
\text { ig } \\
\text { hts }\end{array}$ & $\begin{array}{l}\text { g, T } \\
\text { tex }\end{array}$ & $\begin{array}{l}\text { (longit } \\
\text { (average } \\
\text { able l) } \\
\text { t), (b) wi }\end{array}$ & & $\begin{array}{l}\text { inal) and } v(\mathrm{t} \\
\text { in km) base } \\
\text { d from Table } \\
\text { weight } \mathrm{l} \text { for }\end{array}$ & $\begin{array}{l}\text { transver } \\
d \text { on cc } \\
\text { e } 2 \text { of } 1 \\
\text { all data }\end{array}$ & $\begin{array}{l}f \\
\text { be }\end{array}$ & $\begin{array}{l}\text { in } \mathrm{km} / \mathrm{sec} \\
\text { ined data } \\
\text { nt paper; } \\
=\text { number }\end{array}$ \\
\hline
\end{tabular}


$\pm 20 \mathrm{~km}$. The probable error for $V$ obtained from a single shock is about $\pm 0.2 \mathrm{~km} / \mathrm{ser}$, that for $v$ about $\pm 0.1 \mathrm{~km} / \mathrm{sec}$.

The results of the solutions (b) have been plotted in Figure $t$ with indication of the probable error's for each average depth. As mentioned, smooth curves for $V$ and for $v$ as function $h$ can be drawn which include the results obtained from travel time curves of waves refracted just. below the Mohorovičic discontinuity (Gutenberg, 1959a). The minima of both curves in Figure 4 are slightly smaller than the velocities found for $\mathrm{Pa}$ and $\mathrm{Sa}$ respectively, as it has to be expected if these are channel waves. The slope of the beginning of both velocity-depth curves is greater than that given by $d V / d r=V / r$ and $d v / d r=v / r$ respectively, so that in the average continent the low-velocity chanel for $\mathrm{P}$ as well as for $S$ begins at the Mohorovičic discontinuity.

Unfortunately, the distribution of epicenters of deep-focus shocks for which enough arrival times at nearby stations have been reported to find the apparent velocity at the point of inflection of the travel time curves is very uneven. The great majority of the epicenters which have been used are in the region of Japan, the Mariannas and the Kurile Islands. An attempt has been made to calculate velocities as function of depth for a combination of data obtained for earthquakes in the Hindu Kush regrion and in Rumania. The resulting velocities for $P$ at depths of between 100 and $250 \mathrm{~km}$ are in the average about $0.05 \mathrm{~km} / \mathrm{sec}$ smaller than those for the total (that is, mainly the Japanese area), those for $\mathrm{S}$ are about $0.1 \mathrm{~km} / \mathrm{sec}$ smaller for depths near $120 \mathrm{~km}$, about 0.02 $\mathrm{km} / \mathrm{sec}$ greater for depths between 150 and $250 \mathrm{~km}$. All these differences are within the limits of errors, considering the relatively small numbers of useful shocks (25 for P, 12 for.S) in the Hindu Kush and Rumaniar areas. However, there is no doubt that there are small local differences, especially under ocean bottoms. Unfortunately, no data exist or can be expected there to apply our method. However, the velocities found from waves refracted immediately below the Mohorovičic discontinuity leave no doubt (Gutenberg, 1959a) that the beginning of the velocitydepth curves for the mantle under oceanic areas differs somewhat from that under continents, although the channel exists under both.

In addition to small local differences in the velocity-depth curves, the varying depth of the Mohorovičic discontinuity can be expected to result in differences between the shadow zones (Figure 1) in different regions. Where, under otherwise equal conditions, the discontinuity is relatively deep, the channel can be expected to be relatively narrow; the velocity which exists immediately below the discontinuity there can 
be expected to be reached again at a shallower depth than in regions where the discontinuity is at a smaller depth (compare Figure 4). Consequently, the low-velocity zone should be thicker under oceans than under continental lowlands, as has been found by Landisman, Sato and Fwing (1959) and should have a minimum thickness under roots of mountains.

Table 4

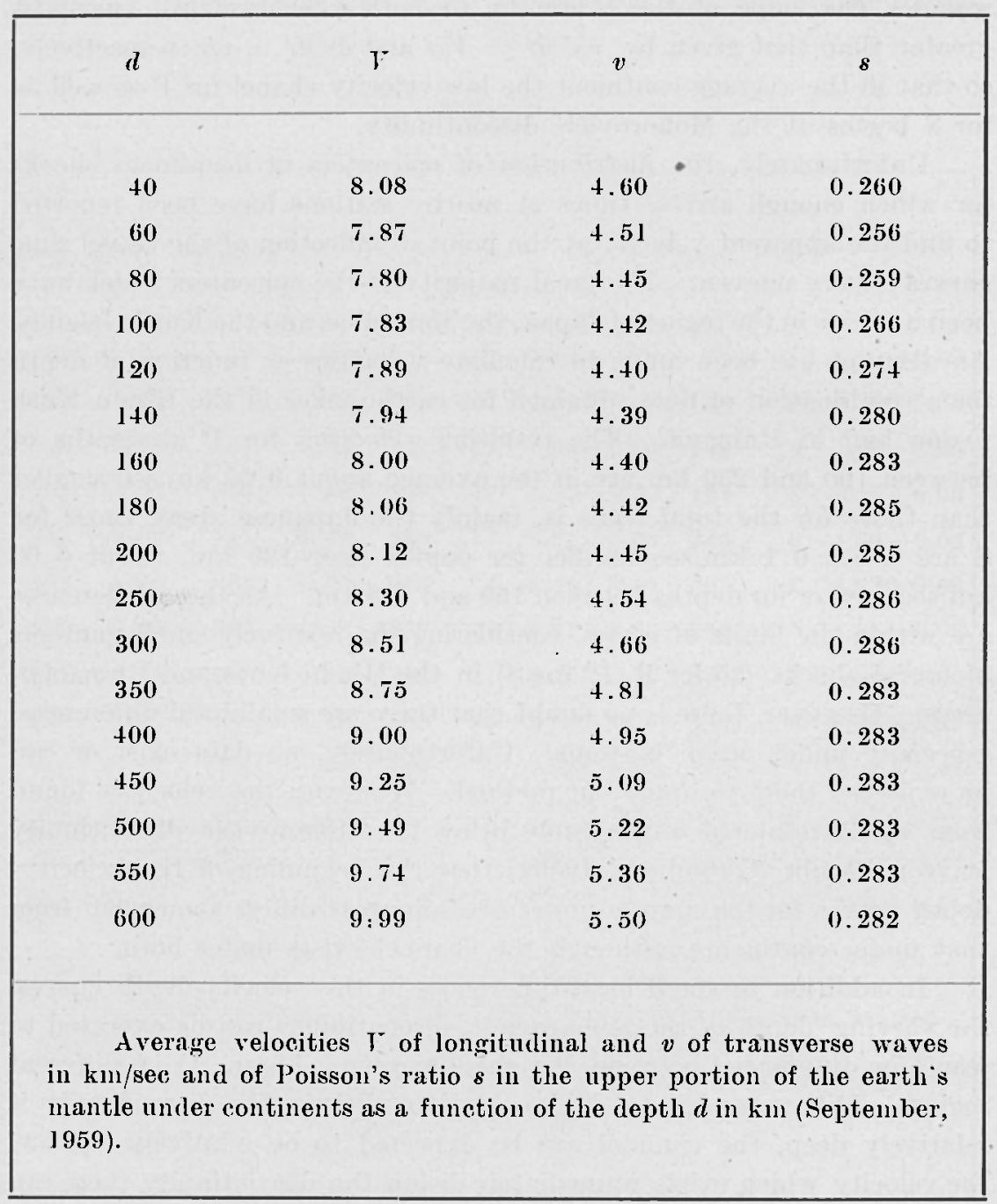


Poisson's ratio is close to 0.26 immediately below the Mohorovičic discontinuity, increases to about 0.28 in the lower portion of the channel (Table 4) and reaches a maximum of nearly 0.29 at depths of about 200 to $250 \mathrm{~km}$; in the whole remainder of the mantle it is between about 0.28 and 0.30 . It is interesting that below the channel it does not decrease again to the value of 0.26 which it has near the top of the mantle.

Contributiou N. 940 - Division of the Geological Sciences - California Institute of Technology, Pasadena, California.

\section{ABSTRACT}

Results based on observations of various phenomena practically prove the existence of a world-wide low-velocity asthenosphere channel. Combination of new and earlier data on seismic wave velocities show that under continents the channel begins at the Mohorovicic discontinuity with velocities which are the smaller the greater the depth of the discontinuity. They are about 8.1 and $4.6 \mathrm{~km} / \mathrm{sec}$ for longitudinal and transverse waves respectively, if the discontinuity is at a depth of $40 \mathrm{~km}$. Longitudinal waves have a minimum velocity of about $7.8 \mathrm{~km} / \mathrm{sec}$ near a depth of $80 \mathrm{~km}$, transverse waves a minimum of about $4.4 \mathrm{~km} / \mathrm{sec}$ near a depth of $150 \mathrm{~km}$. The velocity which exists at a depth of $40 \mathrm{~km}$ under continents is reached again at a depth of about $190 \mathrm{~km}$ by longitudinal waves and at a depth near $270 \mathrm{~km}$ by transverse waves. The rate of decrease in velocity immediately below the discontinuity is in the average greater than the critical rate for formation of shadow zones. There is no indication of a discontinuity in the upper portion of the mantle. Poisson's ratio is nearly constant, 0.26, down to a depth of about $80 \mathrm{~km}$, and increases in the asthenosphere channel to almost 0.29. Below the channel, it does not return to the value of 0.26 but remains nearly constant in most of the deeper portions of the mantle.

\section{RIASSUNTO}

Risultati basati su osservazioni di vari fenomeni provano praticamente l'esistenza di un canale astenosferico a flessione di velocità, diffuso in tutta la terra. L'unione di dati passati e recenti nella velocità dell'onda sismica mostra che sotto $i$ continenti il canale comincia alla discontinuità di Moho- 
rovicic, con velocità che sono tanto più piccole quanto più grande è la profondità della discontinuità.

Esse sono circa di 8.1 e $4.6 \mathrm{~km} / \mathrm{sec}$. rispettivamente per le onde longitudinali e trasversali, se la discontinuità è a una profondità di $40 \mathrm{~km}$. Le onde longitudinali hanno una velocità minima di $7.8 \mathrm{~km} / \mathrm{sec}$ circa intorno ad una profondità di $80 \mathrm{~km}$, le onde trasversali una velocità minima di 4.4 $\mathrm{km} / \mathrm{sec}$ circa intorno a una profondità di $150 \mathrm{~km}$. La velocità esistente ad una profondità di $40 \mathrm{~km}$ sotto $i$ continenti è nuovamente raggiunta ad una profondità di circa $190 \mathrm{~km}$ dalle onde longitudinali, ed ad una profondità di circa $270 \mathrm{~km}$ dalle onde trasversali.

L'ordine di decrescita nella velocità immediatamente al disotto della discontinuità è in media più grande che l'ordine critico per la formazione nelle zone d'ombra. Non vi è alcun segno di una discontinuità nella parte superiore del mantello.

Il coefficiente di Poisson è quasi costante, 0.26, sotto una profondità di $80 \mathrm{~km}$ circa, e cresce nel canale astenosferico a quasi 0.29 . Sotto il canale, esso non torna al valore di 0.26 ma rimane quasi costante nella maggioranza delle parti più profonde del mantello.

\section{REFERENCES}

Anonymous, Report of the conference of experts to study the methods of detecting violations of a possible agreement on the suspension of nuclear tests. Exp./Nuc. 28, 26, (1958). See also: Romney, C., "Jour, Geophis. Res. » 64, $1489-1498$ (1959).

BARRELL, J., The strength of the earth's crust. "Jour. Geol.", 22, 23, many installmeuts, (1914).

B\&тI, M., Shadow zones, travel times, and energies of longitudinal seismic waves in the presence of an asthenosphere low-velocity layer. "Trans. Amer. Geophys. Un. ", 38, 526-538, (1957).

B1RCH, F., Interpretation of the seismic structure of the crust in the light of experimental studies of wave velocities in rocks. In: "Contributions in Geophysics ", Pergamon Press, 1, 158-170, (1958).

Bullen, K. E., An introduction to the theory of seismology, 296, Cambridge Univ. Press, 1953.

ByerLy, P., The Montana earthquake of June 28, 1925. "Bull. Seismol. Soc. Amer. ", 16, 209-265, (1926).

CaLoI, P., Onde longitudinali e transversali guidate dall'astenosphera. "Rend. Accad. Lincei (8)", 15, 352-357 (1953).

- L'astenosphera come canale-guida dell'energia sismica. "Ann. di Geofis.", 7, 491-501, (1954). 
DALY, R. A., Strength and structure of the earth, 434, Prentice-Hall, 1940.

Dorman, J., EWING, M., and OLIver, J., Study of shear velocity distribution in the upper mantle by surface wave analysis. Pt. 1: Mantle Rayleigh waves (Abstract). Program 1959 meeting, Cordilleran Sect. Geol. Soc. Amer., 21, (1959).

GILVARRY, J. J., Temperature in the earth's interior. " Jour. Atmosph. Terrest. Phys. ", 10, 84-95, (1957).

Gorshкov, G. S., On some theoretical problems of volcanology. "Bull. Velcan.». Ser. II, 19, 26-29 and 103-113, (1958).

GUtenberG, B., Untersuchungen zur Frage, bis zu welcher Tiefe die Erde kristallin ist. "Zeitschr. Geophys. ", 2, 24-29, (1926).

- Magnitude determination for deep-focus earthquakes. "Bull. Seismol. Soc. Amer. ", 35, 117-130, (1945).

- On the layer of relatively low wave velocity at a depth of about 80 kilometers. "Bull. Seismol. Soc. Amer. ", 38, 121-148, (1948).

- The cooling of the earth and the temperature in its interior. In: "Internal constitution of the earth ", Dover Publ. 150-166, (1951).

- Wave velocities at depths between 50 and 600 kilometers. "Bull. Seismol. Soc. Amer. ", 43, 223-232, (1953).

- Low-velocity layers in the earth's mantle. "Bull. Seismol. Soc. Amer.", $65,337-348$, (1954a).

- Effects of low-velocity layers. "Geofis. Pura e Applic. ", 28, 1-10, (1954b).

- Wave velocities in the earth's crust. "Geol. Soc. Amer.", Spec. Paper., 62, 19-34, (1955a).

- Channel waves in the earth's crust. "Geophysics ", 20, 283-294, (1955b).

- Velocity of seismic waves in the earth's mantle. "Trans. Amer. Geophys" Un. n, 39, 486-489, (1958).

- Wave velocities below the Mohorovicic discontinuity. "Geophys. Journal . (in press), (1959a).

- Physics of the earth's interior, 240, Academic Press, 1959b.

Gutenberg, B., and Richter, C. F., On seismic waves (second paper). "Gerlands Beiträge zur Geophysik ", 45, 280-360, (1935).

- New evidence for a change in physical conditions at depths near 100 kilo. meters. "Bull. Seismol. Soc. Amer.", 29, 531-537, (1939).

Hughes, D. S., and MadRetTes, C., Variations of elastic wave velocities in basic igneous rock with pressure and temperature. "Geophysics", 22, 23-31, (1957).

J (1956). 
Jefrreys, H., The Earth, 3rd ed., 392, Cambridge Univ. Press, 1952.

- The Earth, 4th. ed., 420, Cambridge Univ. Press, 1959.

Jeffreys, H., and Bullen, K. E., Seismological Tables. Brit. Assoc. Adv. Science, 48, (1940).

Landisman, M., Sato, Y., and EwIng, M., Surface wave dispersion in elastic media having gradients in their physical properties (Abstract). "Jour. Geophys. Res. ", 64, 1113, (1959).

Lubimova, H. A., Thermal history of the earth with consideration of the variable thermal conductivity of its mantle. "Geophys. Journal ", 1, 115-134, (1958).

Press, F., Some implications on mantle and crustal structure from $G$-wave and Love waves. "Jour. Geophys. Res. ", 64, 565-568, (1959).

Takeuchi, H., Press, F., and Ковауаsir, N., On mantle Rayleigh waves (Abstract). Program 1959 meeting, Cordilleran Sect. Geol. Soc. Amer., 58, (1959). See also: "Bull. Seismol. Soc. Amer." 49, 355-364, (1995).

UFFEN, R. J., A method of estimating the melting point gradient in the earth's mantle. "Transact. Amer. Geophys. Un. ", 33 893-896, (1952).

VALLE, P. E., Sul gradiente di temperatura necessario per la formazione di "low-velocity layers". "Annali di Geofis", 9, 371-378, (1956).

Vesanen, E., Nurmia, M., and Porkxa, M. T., New evidence for the existence of Gutenberg's asthenosphere channel. "Geophysica" (Helsinki), 7 (in press).

VerIOOGEN, J., Temperatures within the earth. In: "Physics and Chemistry of the earth ", McGraw Hill, 1, 17-43, (1956). 